\title{
Methylphenidate and Atomoxetine Inhibit Social Play Behavior through Prefrontal and Subcortical Limbic Mechanisms in Rats
}

\author{
E.J. Marijke Achterberg, ${ }^{1 \star}$ Linda W.M. van Kerkhof, ${ }^{2 *}$ Ruth Damsteegt, ${ }^{2}$ Viviana Trezza, ${ }^{3}$ \\ and Louk J.M.J. Vanderschuren ${ }^{1,2}$ \\ ${ }^{1}$ Department of Animals in Science and Society, Division of Behavioural Neuroscience, Faculty of Veterinary Medicine, Utrecht University, 3584 CM \\ Utrecht, The Netherlands, ${ }^{2}$ Department of Translational Neuroscience, Brain Center Rudolf Magnus, University Medical Center Utrecht, 3584 CG Utrecht, \\ The Netherlands, and 3Department of Science, Section of Biomedical Sciences and Technologies, University "Roma Tre," 00146 Rome, Italy
}

Positive social interactions during the juvenile and adolescent phases of life, in the form of social play behavior, are important for social and cognitive development. However, the neural mechanisms of social play behavior remain incompletely understood. We have previously shown that methylphenidate and atomoxetine, drugs widely used for the treatment of attention-deficit hyperactivity disorder (ADHD), suppress social play in rats through a noradrenergic mechanism of action. Here, we aimed to identify the neural substrates of the play-suppressant effects of these drugs. Methylphenidate is thought to exert its effects on cognition and emotion through limbic corticostriatal systems. Therefore, methylphenidate was infused into prefrontal and orbitofrontal cortical regions as well as into several subcortical limbic areas implicated in social play. Infusion of methylphenidate into the anterior cingulate cortex, infralimbic cortex, basolateral amygdala, and habenula inhibited social play, but not social exploratory behavior or locomotor activity. Consistent with a noradrenergic mechanism of action of methylphenidate, infusion of the noradrenaline reuptake inhibitor atomoxetine into these same regions also reduced social play. Methylphenidate administration into the prelimbic, medial/ventral orbitofrontal, and ventrolateral orbitofrontal cortex, mediodorsal thalamus, or nucleus accumbens shell was ineffective. Our data show that the inhibitory effects of methylphenidate and atomoxetine on social play are mediated through a distributed network of prefrontal and limbic subcortical regions implicated in cognitive control and emotional processes. These findings increase our understanding of the neural underpinnings of this developmentally important social behavior, as well as the mechanism of action of two widely used treatments for ADHD.

Key words: amygdala; habenula; methylphenidate; noradrenaline; prefrontal cortex; social play behavior

\section{Introduction}

Social play behavior is a vigorous form of social interaction that is abundantly expressed in the juvenile and adolescent of most mammalian species, including humans. It is thought that social play behavior has an important role in social, cognitive, and emotional development (Fagen, 1981; Panksepp et al., 1984; Vanderschuren et al., 1997; Špinka et al., 2001; Pellis and Pellis, 2009; Graham and Burghardt, 2010; Baarendse et al., 2013; Vanderschuren and Trezza, 2014). However, our knowledge of the neu-

\footnotetext{
Received July 18, 2014; revised Oct. 24, 2014; accepted Nov. 5, 2014

Author contributions: M.E.J.A., L.W.M.v.K., V.T., and L.J.V. designed research; M.E.J.A., L.W.M.v.K., R.D., and V.T. performed research; M.E.J.A., L.W.M.v.K., R.D., and V.T. analyzed data; M.E.J.A., L.W.M.v.K., V.T., and L.J.M.J.V. wrote the paper.

This work was supported by National Institute on Drug Abuse (Grant R01 DA022628 to L.J.M.J.V.), the Netherlands Organization for Scientific Research (NWO Veni Grant 91611052 to V.T.), and by Marie Curie Career Reintegration Grant (PCIG09-GA-2011-293589 to V.T.).

The authors declare no competing financial interests.

*E.J.M.A. and L.W.M.v.K. contributed equally to this work

Correspondence should be addressed to Louk J.M.J. Vanderschuren, PhD, Department of Animals in Science and Society, Division of Behavioural Neuroscience, Faculty of Veterinary Medicine, Utrecht University, Yalelaan 2, 3584 CM Utrecht, The Netherlands. E-mail: I.j.m.j.vanderschuren@uu.nl.

DOI:10.1523/JNEUROSCI.2945-14.2015

Copyright $\odot 2015$ the authors $\quad 0270-6474 / 15 / 350161-09 \$ 15.00 / 0$
}

ral mechanisms underlying social play is limited (Vanderschuren et al., 1997; Trezza et al., 2010; Siviy and Panksepp, 2011; Vanderschuren and Trezza, 2014). Identifying the neural underpinnings of social play will increase our understanding of adaptive behavioral development and of the etiology of childhood and adolescent psychiatric disorders characterized by social impairments, such as autism and attention-deficit/hyperactivity disorder (ADHD).

Pharmacological modulation of social play behavior has revealed that psychomotor stimulants such as amphetamine and methylphenidate profoundly inhibit social play (Beatty et al., 1982, 1984; Thor and Holloway, 1983; Sutton and Raskin, 1986; Vanderschuren et al., 2008; Achterberg et al., 2014). Importantly, we have previously shown that methylphenidate and amphetamine inhibit social play through a noradrenergic mechanism of action. Their play-suppressant effect was mimicked by the noradrenaline reuptake inhibitor atomoxetine, but not the dopamine reuptake inhibitor GBR12909, and their effect on social play was blocked by pretreatment with an $\alpha 2$-adrenoceptor antagonist, but not a dopamine receptor antagonist (Vanderschuren et al., 2008; Achterberg et al., 2014). Moreover, combined administration of subeffective doses of methylphenidate 
and atomoxetine reduced social play behavior (Vanderschuren et al., 2008), indicating that methylphenidate and atomoxetine inhibit social play behavior through a common, noradrenergic mechanism of action. Interestingly, methylphenidate, amphetamine, and atomoxetine are widely used to treat ADHD (Kutcher et al., 2004; Kratochvil et al., 2006; Feldman and Reiff, 2014). Therefore, investigating their effects on social behavior in young animals may help to understand their mechanism of action and potential side effects in the treatment of ADHD.

We previously hypothesized that the effects of methylphenidate and atomoxetine on social play were related to enhanced behavioral inhibition (Vanderschuren et al., 2008) because these drugs facilitate several aspects of cognitive control (Chamberlain and Sahakian, 2007; Eagle et al., 2008; Pattij and Vanderschuren, 2008) through prefrontal corticostriatal circuits (Arnsten, 2011; Del Campo et al., 2011). In addition, these drugs could influence social play behavior by altering its emotional properties (Andersen, 2005; Trezza et al., 2010; Siviy and Panksepp, 2011). Therefore, to identify the neural sites of action through which methylphenidate reduces social play, we infused this drug into several prefrontal and orbitofrontal regions, the nucleus accumbens shell, mediodorsal thalamus, basolateral amygdala (BLA), and habenula. These regions have been implicated in cognitive and emotional processes (McAlonan et al., 1993; Chudasama et al., 2001; Miller and Cohen, 2001; Baxter and Murray, 2002; Cardinal et al., 2002; Phelps and LeDoux, 2005; Block et al., 2007; Lecourtier and Kelly, 2007; Robbins and Arnsten, 2009; Schoenbaum et al., 2009; Hikosaka, 2010; Morrison and Salzman, 2010; Berridge and Kringelbach, 2013), including social play (Siviy and Panksepp, 1985; Panksepp et al., 1994; Schneider and Koch, 2005; Pellis et al., 2006; Bell et al., 2009; Trezza et al., 2011a, 2012; van Kerkhof et al., 2013a, 2013b, 2014), and receive a well characterized noradrenergic innervation (Moore and Bloom, 1979; Gottesfeld, 1983; Unnerstall et al., 1984; Berridge et al., 1997; Delfs et al., 1998; Lecourtier and Kelly, 2007). To test whether the effect of methylphenidate on social play depended on noradrenergic neurotransmission, we next infused atomoxetine into brain regions in which methylphenidate was found to inhibit social play behavior.

\section{Materials and Methods}

Animals. Male Wistar rats (Charles River) arrived in our animal facility on postnatal day $(\mathrm{P}) 21$. They were housed in groups of four in $40 \times 26 \times$ $20(1 \times \mathrm{w} \times \mathrm{h}) \mathrm{cm}$ Macrolon cages under controlled conditions (i.e., temperature $20-21^{\circ} \mathrm{C}, 55-65 \%$ relative humidity, and $12 / 12 \mathrm{~h}$ light cycle with lights on at 7:00 A.M.). Food and water were available ad libitum. During the first $6 \mathrm{~d}$ after arrival, the rats were handled at least twice. All experiments were approved by the Animal Ethics Committee of Utrecht University and were conducted in accordance with Dutch legislation (Wet op de Dierproeven, 1996) and European regulations (Guideline 86/609/EEC).

Surgical procedures. The surgical procedures were based on previous experiments (Trezza et al., 2011a; Trezza et al., 2012; van Kerkhof et al., 2013a, 2013b). On P26-P27, the rats were anesthetized subcutaneously with $0.08 \mathrm{ml} / 100 \mathrm{~g}$ Hypnorm (fentanylcitrate $0.315 \mathrm{mg} / \mathrm{ml}$ and fluanison $10 \mathrm{mg} / \mathrm{ml}$; Janssen) and positioned into a stereotactic frame (David Kopf Instruments). Guide cannulae (24 gauge microblasted thin-walled stainless steel; Cooper's Needleworks) were implanted bilaterally. The cannulae were aimed $0.5 \mathrm{~mm}$ above the anterior cingulate cortex [coordinates: anterior-posterior $(\mathrm{AP})+2.6 \mathrm{~mm}$ from bregma; medial-lateral $(\mathrm{ML}) \pm$ $0.8 \mathrm{~mm}$ from the midline; dorsal-ventral (DV) $-2.4 \mathrm{~mm}$ from skull surface], prelimbic cortex (coordinates: AP $+2.6 \mathrm{~mm}$; $\mathrm{ML} \pm 0.8 \mathrm{~mm}$; $\mathrm{DV}-3.2 \mathrm{~mm}$ ), infralimbic cortex (coordinates: $\mathrm{AP}+2.6 \mathrm{~mm} ; \mathrm{ML} \pm 0.8$ $\mathrm{mm}$; DV $-4.1 \mathrm{~mm}$ ), medial/ventral orbitofrontal cortex (coordinates: $\mathrm{AP}+3.3 \mathrm{~mm} ; \mathrm{ML} \pm 0.8 \mathrm{~mm}$; $\mathrm{DV}-5.3 \mathrm{~mm}$ ), ventrolateral orbitofrontal cortex (coordinates: AP $+3.3 \mathrm{~mm}$; $\mathrm{ML} \pm 1.9 \mathrm{~mm}$; DV $-4.2 \mathrm{~mm}$ ), mediodorsal thalamus (coordinates: $\mathrm{AP}-2.4 \mathrm{~mm}$; $\mathrm{ML} \pm 0.8 \mathrm{~mm}$; DV -5.3 $\mathrm{mm}$ ), habenula (coordinates: $\mathrm{AP}-3.0 \mathrm{~mm}$; $\mathrm{ML} \pm 0.8 \mathrm{~mm}$; DV -4.7 $\mathrm{mm}$ ), $1.0 \mathrm{~mm}$ above the nucleus accumbens shell (coordinates: AP $+1.5 \mathrm{~mm}$; ML $\pm 0.8 \mathrm{~mm}$; DV $-5.3 \mathrm{~mm}$ ), or BLA (coordinates: AP -1.9 $\mathrm{mm} ; \mathrm{ML} \pm 4.4 \mathrm{~mm} ; \mathrm{DV}-7.8 \mathrm{~mm}$ ). Coordinates were based on previous experiments (Trezza et al., 2011a, 2012; van Kerkhof et al., 2013a, 2013b) or determined by pilot placements in 28 -d-old rats. Cannulae were secured with stainless steel screws and dental acrylic. Stainless steel stylets (29 gauge) were inserted into the guide cannulae to maintain patency. After surgery, rats were individually housed for $4 \mathrm{~d}$ to recover, after which they were housed with their original cage mates.

Drugs and infusion procedures. Methylphenidate- $\mathrm{HCl}(5.0 \mu \mathrm{g} / 0.3 \mu \mathrm{l}$; Sigma) was dissolved in saline; vehicle infusions contained saline only. Atomoxetine- $\mathrm{HCl}(10.0 \mu \mathrm{g} / 0.3 \mu \mathrm{l}$; Tocris Bioscience) was dissolved in $50 \%$ dimethylsulfoxide (DMSO)/50\% saline; vehicle infusions consisted of $50 \%$ DMSO/50\% saline. The potential neurotoxicity of DMSO may be a point of concern when using it as an injection vehicle. Neurotoxic effects of DMSO have been reported after 10 systemic injections (Cavaletti et al., 2000); however, this treatment schedule had only marginal effects on behavior (Authier et al., 2002). In our studies, DMSO was given for a maximum of three times in a small amount and volume. Furthermore, our histological analysis did not reveal any sign of tissue damage in rats infused with DMSO. Because we found no major differences in behavior between animals that received infusions with saline (the vehicle for methylphenidate) or DMSO (the vehicle for atomoxetine), we consider it unlikely that neurotoxic effects of DMSO have influenced the data. Drug doses were based on previous studies (Zheng et al., 2008; Tye et al., 2010) and pilot experiments. Infusion procedures were as described previously (Trezza et al., 2011a, 2012; van Kerkhof et al., 2013a, 2013b). In short, bilateral infusions were administered using 30-gauge injection needles (Bilaney) that were connected to $10 \mu$ l Hamilton microsyringes by polyethylene (PE-20) tubing. Over $60 \mathrm{~s}, 0.3 \mu \mathrm{l}$ of drug or vehicle solution was infused using a syringe pump (model 975A; Harvard Apparatus) and the injectors were left in place for another $60 \mathrm{~s}$ to allow for diffusion. After the procedure, stylets were replaced and animals were left in a holding cage for $5 \mathrm{~min}$ before testing.

Behavioral testing. Experiments were performed as described previously (Trezza and Vanderschuren, 2008; Vanderschuren et al., 2008) in a sound-attenuated chamber under red light conditions. The testing arena was a Plexiglas cage $(40 \times 40 \times 60 \mathrm{~cm} ; 1 \times \mathrm{w} \times \mathrm{h})$ with $\sim 2 \mathrm{~cm}$ of wood shavings covering the floor. Animals were paired with an unfamiliar partner (i.e., not a cage mate). Animals in a test pair did not differ $>10 \mathrm{~g}$ in body weight. Animals arrived in the facility at P21 and underwent surgery on P26 or P27. After surgery, the rats were habituated to the experimental procedures on 2 consecutive days. On the first habituation day (P32), rats were individually placed into the test cage for $10 \mathrm{~min}$. On the second habituation day (P33), the animals were socially isolated for $2.5 \mathrm{~h}$. Pairs of rats were then infused with vehicle solutions and placed into the test cage for $15 \mathrm{~min}$ to habituate them to the infusion and testing procedures. On the third day (P34), which was the first test day, rats were isolated for $2.5 \mathrm{~h}$. Both rats in a pair were then simultaneously infused with either drug (methylphenidate or atomoxetine) or vehicle before testing. On the second test day (P36), the animals were also isolated for $2.5 \mathrm{~h}$ and treatments were reversed so that animals that received drug (methylphenidate or atomoxetine) treatment on the first test day now received vehicle and vice versa. The first and second test day were separated by a wash-out day (P35) during which the animals received no treatment and were not tested. Therefore, the effects of methylphenidate and atomoxetine on social play behavior were investigated using a within-subjects design except for the experiment in which methylphenidate was infused into the BLA. Because of technical issues, in this experiment, two independent groups of animals received either vehicle or methylphenidate and were tested once.

In the first set of experiments, we determined the brain regions in which methylphenidate affected social play behavior by infusing it into the anterior cingulate cortex, prelimbic cortex, infralimbic cortex, medial/ventral orbitofrontal cortex, ventrolateral orbitofrontal cortex, mediodorsal thalamus, habenula, nucleus accumbens shell, or BLA. We have 


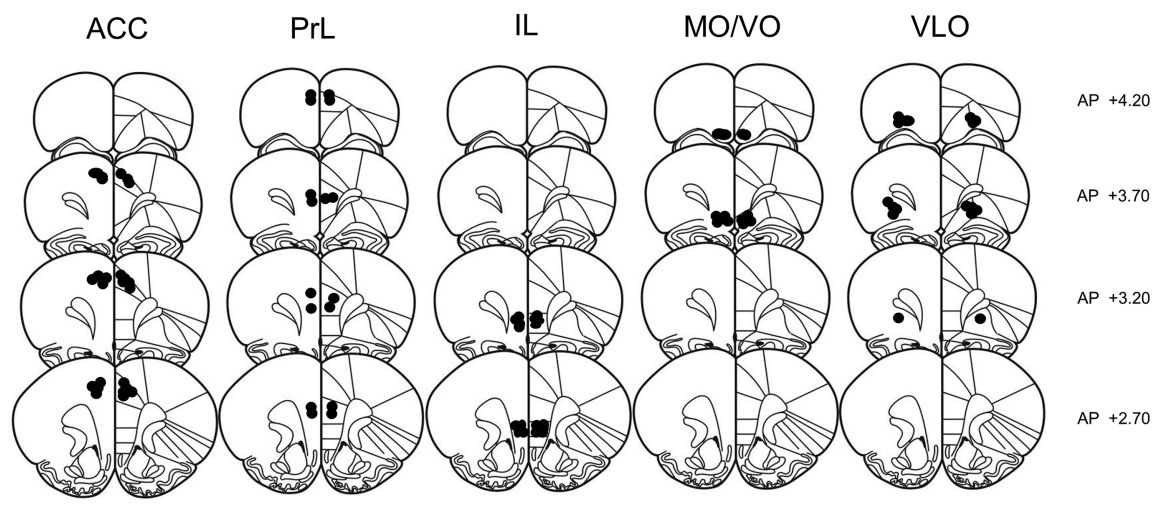

Figure 1. Schematic representation of brain sections with microinjection placements in the anterior cingulate cortex (ACC), prelimbic cortex (PrL), infralimbic cortex (IL), medial/ventral orbitofrontal cortex (MO/V0), and ventrolateral orbitofrontal cortex (VL0). (Adapted with permission from Paxinos and Watson, 2007).
NAc shell

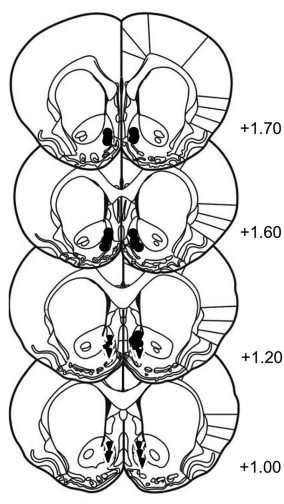

BLA

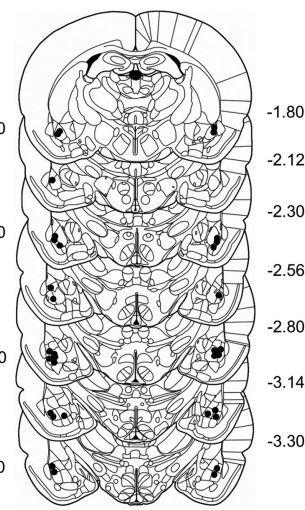

Habenula

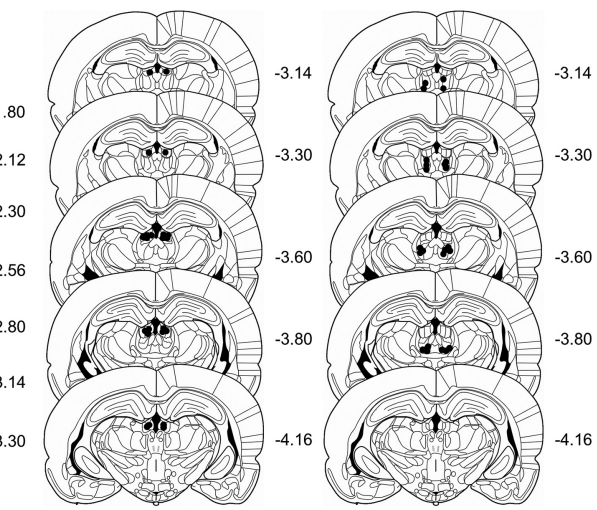

Figure 2. Schematic representation of brain sections with microinjection placements in the nucleus accumbens (NAc) shell, basolateral amygdala (BLA), habenula, and mediodorsal (MD) thalamus. (Adapted with permission from Paxinos and Watson, 2007).

previously found that the effect of methylphenidate on social play behavior relies on noradrenergic neurotransmission (Vanderschuren et al., 2008). Therefore, in the second, independent set of experiments, we tested the hypothesis that intracranial administration of methylphenidate inhibits social play behavior through a noradrenergic mechanism of action by infusing atomoxetine into the brain regions in which we found methylphenidate to reduce social play behavior.

Testing consisted of placing a pair of animals into the arena for $15 \mathrm{~min}$. Behavior of the animals was recorded using a camera with zoom lens, video tape recorder, and television monitor. The behavior of the rats was assessed using Observer 5.1 software (Noldus Information Technology). The structure of social play behavior in rats has been described previously in detail (Bolles and Woods, 1964; Baenninger, 1967; Poole and Fish, 1975; Panksepp and Beatty, 1980; Pellis and Pellis, 1987; Pellis et al., 1989, for reviews see Panksepp et al., 1984; Vanderschuren et al., 1997; Pellis and Pellis, 1998; Trezza et al., 2010). In rats, a bout of social play behavior starts with one rat soliciting ("pouncing") another animal by attempting to nose or rub the nape of its neck. The animal that is pounced upon can respond in different ways. If the animal that is pounced upon responds by evading, the soliciting rat may start to chase it, thus making another attempt to launch a play bout. The solicited animal may also rear toward the soliciting animal and the two animals may rapidly push, paw, and grab each other ("boxing"). If the animal that is pounced upon fully rotates to its dorsal surface, "pinning" is the result, meaning one animal lying with its dorsal surface on the floor with the other animal standing over it. From this position, the supine animal can initiate another play bout by trying to gain access to the other animal's neck. Therefore, during social play, pouncing is considered an index of play solicitation and pinning can be regarded as the terminal component of a single play bout as well as a releaser of a prolonged play bout (Poole and Fish, 1975; Panksepp and Beatty, 1980; Pellis and Pellis, 1987; Pellis et al., 1989). Pinning and pouncing frequencies can be easily quantified and are considered the most characteristic parameters of social play behavior in rats (Panksepp and Beatty, 1980). Pinning and pouncing usually occur very rapidly and are of short duration. Therefore, scoring their frequency is more informative than scoring their duration. We have also found that pinning and pouncing are very reliable play parameters that occur consistently and with considerable frequency during playful encounters (see also Panksepp and Beatty, 1980; Vanderschuren et al., 1995), whereas the occurrence of chasing and boxing is quite variable between pairs of animals and experiments. During the tests for social play, the rats also display social behaviors not directly associated with play, such as sniffing or grooming the partner's body (Panksepp and Beatty, 1980; Vanderschuren et al., 1995). Because social play behavior in a rat strongly depends on the playfulness of its partner (Pellis and McKenna, 1992; Trezza and Vanderschuren, 2008), in the present study, both animals in a play pair received the same treatment and a pair of animals was considered as one experimental unit. The following parameters were therefore scored per pair of animals: (1) social behaviors related to play: frequency of pinning and frequency of pouncing; and (2) social behaviors unrelated to play: duration of social exploration: the amount of time spent in nonplayful social interaction (i.e., sniffing or grooming).

To assess whether their effects on social play were related to changes in general activity, the effects of methylphenidate and atomoxetine on horizontal locomotor activity were tested on P37 as described previously (Trezza et al., 2009a; Veeneman et al., 2011). In these experiments, a between-subjects design was used, so that the animals received infusions with methylphenidate, atomoxetine, or vehicle. The infusion protocol was similar to the one described above. After the infusion procedure, rats were transferred to a plastic cage $(50 \times 33 \times 40 \mathrm{~cm}, 1 \times \mathrm{w} \times \mathrm{h})$ and their position was tracked 5 times per second for $30 \mathrm{~min}$ using a video-tracking system (EthoVision, Noldus Information Technology).

Histological confirmation of injection sites. Immediately after the locomotor activity test, the animals were killed using carbon dioxide inhalation and microinjected with $0.3 \mu \mathrm{l}$ of black ink over $1 \mathrm{~min}$ through the guide cannulae, comparable to the drug infusion procedure. After the infusion, animals were immediately decapitated and their brains removed and immediately frozen. Cryostat sections $(20 \mu \mathrm{m})$ were collected and stained with cresyl violet. Placement of the microinjection sides was determined using a light microscope according to the atlas of Paxinos and Watson (2007). Only pairs in which both animals had bilateral needle tracks terminating into the target area were included in the final analysis of social play behavior (Figs. 1,2). As mentioned above, the effects of methylphenidate and atomoxetine on horizontal locomotor activity was assessed per individual animal using a between-subjects design. Therefore, each animal with correct cannula placements was included in the analysis of locomotor activity even if it was not used for the analysis of social play behavior because its partner had incorrect placements (and the pair was therefore excluded).

Statistical analysis. Pinning and pouncing frequencies and time spent on social exploration (in seconds) were scored per pair of animals and 
expressed as mean + SEM. To assess the effect of methylphenidate and atomoxetine administration on social play behavior, data were analyzed using a paired-samples Student's $t$ test. In the experiment in which methylphenidate was administered into the BLA, data were analyzed using an independent Student's $t$ test. Horizontal locomotor activity was assessed per individual animal and expressed as mean \pm SEM traveled distance (in centimeters) in 5 min bins. The effects of methylphenidate and atomoxetine on locomotor activity were analyzed using a one-way repeated-measures ANOVA.

\section{Results}

Methylphenidate infusion into medial prefrontal but not orbitofrontal cortical regions inhibits social play

Infusion of methylphenidate into the anterior cingulate cortex reduced pinning $\left(t_{(6)}=3.10, p=0.02\right)$ and pouncing $\left.t_{(6)}=2.49, p=0.05\right)$ and tended to increase social exploration $\left(t_{(6)}=-2.24, p=\right.$ 0.07 ) (Fig. $3 A-C, n=7$ ). No effect on locomotor activity was found $\left(F_{\text {treatment }(1,14)}=0.43\right.$, $p=0.78 ; F_{\text {time }(5,70)}=19.11, p<0.001 ; F_{\text {time }} \times$ treatment(5,70) $=0.49, p=0.78, n=8)$ (Fig. 3D). After infusion of methylphenidate into the infralimbic cortex (social play behavior: $n=12$; locomotor activity: vehicle $n=7$, methylphenidate $n=9$ ), a reduction in pinning $\left(t_{(11)}=2.46, p=\right.$ $0.03)$ and pouncing $\left(t_{(11)}=2.47, p=\right.$ 0.03 ) (Fig. $4 A, B$ ) but not social exploration $\left(t_{(11)}=-1.16, p=0.13\right)$ or locomotor activity $\left(F_{\text {treatment }(1,14)}=0.43, p=0.78 ; F_{\text {time }(5,70)}=\right.$ $16.05, p<0.001 ; F_{\text {time }} \times$ treatment $(5,70)=0.44$, $p=0.84$ ) (Fig. 4C,D) was found.

Treatment with methylphenidate in the prelimbic cortex, the medial/ventral orbitofrontal cortex, and ventrolateral orbitofrontal cortex did not affect social play or social exploratory behavior (Table 1).

Methylphenidate infusion into the BLA and habenula, but not nucleus accumbens shell or mediodorsal thalamus, reduces social play

Infusion of methylphenidate into the BLA $(n=6)$ reduced the frequency of pinning $\left(t_{(10)}=2.73, p=0.02\right)$ and pouncing $\left(t_{(10)}\right.$ $=2.82, p=0.02)$ without changing social exploration $\left(t_{(10)}=\right.$ $0.86, p=0.41)$ or locomotor activity $\left(F_{\text {treatment }(1,17)}=0.22, p=\right.$ $0.65 ; F_{\text {time }(5,85)}=26.48, p<0.001 ; F_{\text {time }} \times \operatorname{treatment}(5,85)=0.75$, $p=0.59$; Fig. $5 A-D)$.

A reduction in the frequency of both play parameters was also observed after administration of methylphenidate into the habenula $(n=9)$ (pinning: $t_{(8)}=4.87, p=0.001$; pouncing: $t_{(8)}=$ $5.58, p=0.001$ ) (Fig. $6 A, B$ ). No changes were observed in the time spent on social exploration $\left(t_{(8)}=-0.19, p=0.85\right)$ or in locomotor activity $\left(F_{\text {treatment }(1,18)}=0.15, p=0.71 ; F_{\text {time }(5,90)}=\right.$ 49.34, $p<0.001 ; F_{\text {time }} \times$ treatment(5,90) $=0.218, p=0.95$; Fig. $6 C, D)$.
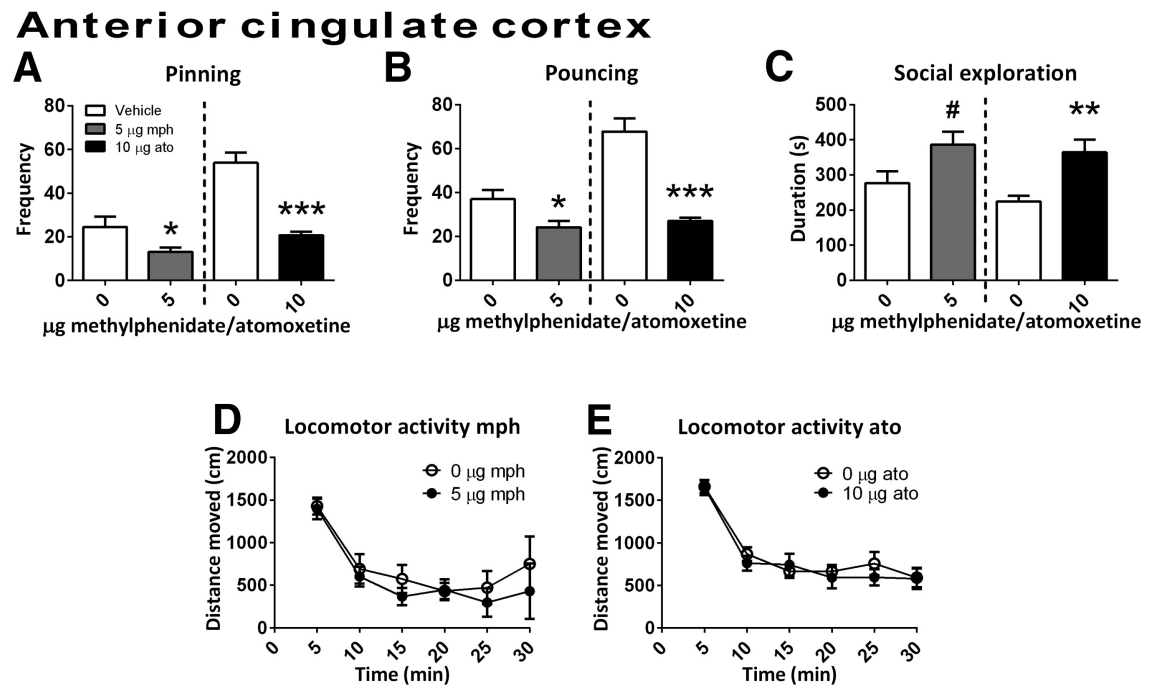

Figure 3. The effect of methylphenidate (mph; $5.0 \mu \mathrm{g} / 0.3 \mu \mathrm{l}$, gray bar; social play behavior, $n=7$; locomotor activity, $n=8$ ) or atomoxetine (ato; $10.0 \mu \mathrm{g} / 0.3 \mu \mathrm{l}$, black bar; social play behavior, $n=8$; locomotor activity: vehicle, $n=8$; atomoxetine, $n=11$ ) administration into the anterior cingulate cortex. Data are presented as mean + SEM. Both methylphenidate and atomoxetine reduced pinning $(\boldsymbol{A})$ and pouncing $(\boldsymbol{B})$ after infusion into the anterior cingulate cortex. Methylphenidate tended to increase and atomoxetine increased social exploration $(\boldsymbol{C})$, but neither drug affected locomotor activity $(\boldsymbol{D}, \boldsymbol{E}) .{ }^{*} p \leq 0.05,{ }^{* *} p \leq 0.01,{ }^{* * *} p<$ $0.001, \# p=0.07$, paired $t$ test.
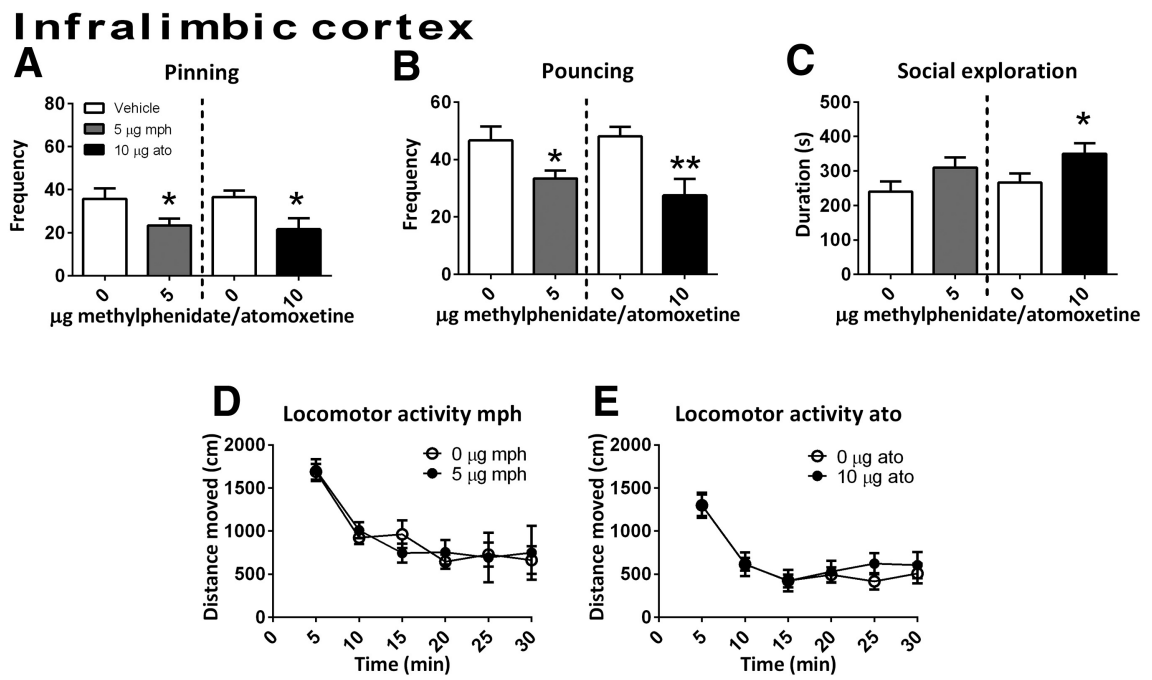

Figure 4. The effect of methylphenidate ( $\mathrm{mph} ; 5.0 \mu \mathrm{g} / 0.3 \mu \mathrm{l}$, gray bar; social play behavior, $n=12$; locomotor activity: vehicle, $n=7$; methylphenidate, $n=9$ ) or atomoxetine (ato; $10.0 \mu \mathrm{g} / 0.3 \mu \mathrm{l}$, black bar; social play behavior, $n=10$; locomotor activity: vehicle, $n=12$; atomoxetine, $n=9$ ) administration into the infralimbic cortex on social play behavior. Data are presented as mean + SEM. Both methylphenidate and atomoxetine infusion into the infralimbic cortex decreased pinning $(\boldsymbol{A})$ and pouncing $(\boldsymbol{B})$. Methylphenidate did not affect and atomoxetine increase social exploration (C). Neither methylphenidate nor atomoxetine infusion into the infralimbic cortex affected locomotor activity $(\boldsymbol{D}, \boldsymbol{E})$. ${ }^{*} p \leq 0.05,{ }^{* *} p \leq 0.01$, paired $t$ test.

Administration of methylphenidate into the nucleus accumbens shell or the mediodorsal thalamus did not affect social play behavior or social exploration (Table 1).

Atomoxetine infusion into the anterior cingulate cortex, infralimbic cortex, BLA, and habenula decreases social play Infusion of atomoxetine into the anterior cingulate cortex (social play behavior: $n=8$; locomotor activity: vehicle $n=8$, atomoxetine $n=11)$ reduced pinning $\left(t_{(7)}=7.68, p<0.001\right)$ and pouncing $\left(t_{(7)}=7.74, p<0.001\right)$ and increased the time spent on social exploration $\left(t_{(7)}=-3.84, p=0.01\right.$ ) (Fig. $3 A-C$ ). However, no effect on locomotor activity was found $\left(F_{\text {treatment }(1,17)}=\right.$ 
Table 1. Methylphenidate infusion into the prelimbic cortex, medial/ventral orbitofrontal cortex, ventrolateral orbitofrontal cortex, nucleus accumbens shell, and mediodorsal thalamus did not affect social play or social exploration

\begin{tabular}{|c|c|c|c|c|}
\hline Brain region & Behavior & Vehicle & Methylphenidate & Statistics \\
\hline \multirow[t]{3}{*}{ Prelimbic cortex $(n=9)$} & Pinning & $27.8 \pm 5.2$ & $31.9 \pm 2.96$ & $t_{(8)}=-0.80, p=0.45$ \\
\hline & Pouncing & $51.1 \pm 8.3$ & $52.8 \pm 3.8$ & $t_{(8)}=-0.19, p=0.79$ \\
\hline & Social exploration & $270.7 \pm 2.5$ & $263.0 \pm 29.8$ & $t_{(8)}=0.28, p=0.79$ \\
\hline \multirow[t]{3}{*}{ Medial/ventral orbitofrontal cortex $(n=7)$} & Pinning & $28.0 \pm 4.7$ & $25.7 \pm 3.8$ & $t_{(6)}=0.45, p=0.67$ \\
\hline & Pouncing & $41.0 \pm 6.0$ & $34.0 \pm 3.9$ & $t_{(6)}=0.78, p=0.47$ \\
\hline & Social exploration & $489.8 \pm 8.6$ & $543.4 \pm 23.6$ & $t_{(6)}=-1.53, p=0.18$ \\
\hline \multirow[t]{3}{*}{ Ventrolateral orbitofrontal cortex $(n=7)$} & Pinning & $33.0 \pm 3.4$ & $28.6 \pm 5.2$ & $t_{(6)}=0.74, p=0.49$ \\
\hline & Pouncing & $47.3 \pm 4.2$ & $47.6 \pm 5.2$ & $t_{(6)}=0.06, p=0.96$ \\
\hline & Social exploration & $216.9 \pm 6.4$ & $218.0 \pm 20.8$ & $t_{(6)}=0.49, p=0.65$ \\
\hline \multirow[t]{3}{*}{ Nucleus accumbens shell $(n=10)$} & Pinning & $38.3 \pm 5.4$ & $34.4 \pm 3.2$ & $t_{(9)}=0.51, p=0.62$ \\
\hline & Pouncing & $64.4 \pm 7.6$ & $62.7 \pm 5.4$ & $t_{(9)}=0.15, p=0.89$ \\
\hline & Social exploration & $249.8 \pm 9.9$ & $293.1 \pm 29.4$ & $t_{(9)}=-0.24, p=0.25$ \\
\hline \multirow[t]{3}{*}{ Mediodorsal thalamus ( $n=5$ ) } & Pinning & $33.6 \pm 7.6$ & $30.8 \pm 3.9$ & $t_{(4)}=0.47, p=0.66$ \\
\hline & Pouncing & $50.8 \pm 6.7$ & $42.8 \pm 3.9$ & $t_{(4)}=0.97, p=0.39$ \\
\hline & Social exploration & $198.0 \pm 4.8$ & $194.8 \pm 12.4$ & $t_{(4)}=0.17, p=0.88$ \\
\hline
\end{tabular}

Data are expressed as mean \pm SEM.

\section{Basolateral amygdala}
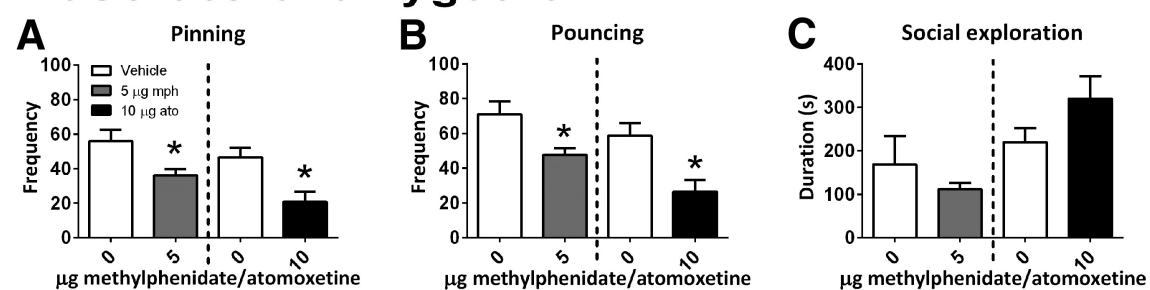

$\mu \mathrm{g}$ methylphenidate/atomoxetine
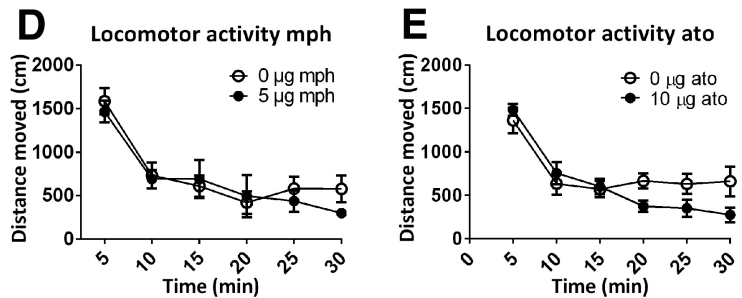

Figure 5. The effect of methylphenidate (mph; $5.0 \mu \mathrm{g} / 0.3 \mu \mathrm{l}$, gray bar; social play behavior, $n=6$; locomotor activity: $n=6$ ) or atomoxetine (ato; $10.0 \mu \mathrm{g} / 0.3 \mu \mathrm{l}$, black bar; social play behavior, $n=6$; locomotor activity: vehicle, $n=9$; atomoxetine, $n=7$ ) administration into the BLA on social play behavior. Data are presented as mean + SEM. Both methylphenidate and atomoxetine reduced pinning $(\boldsymbol{A})$ and pouncing $(\boldsymbol{B})$, but did not affect social exploration $(\boldsymbol{C})$ or locomotor activity $(\boldsymbol{D}, \boldsymbol{E}) .^{*} p<0.05$, independent (mph) or paired (ato) $t$ test. $p=0.05)$ and pouncing $\left(t_{(6)}=3.53, p=\right.$ 0.02 ) (Fig. $6 A, B)$ were reduced, whereas social exploration $\left(t_{(6)}=-1.42, p=0.20\right.$; Fig. $6 C)$ and locomotor activity were not affected $\left(F_{\text {treatment }(1,16)}=2.72, p=0.12\right.$; $F_{\text {time }(5,80)}=50.75, p<0.001 ; F_{\text {time }} \times$ treat $^{-}$ $\operatorname{ment}_{(5,80)}=1.03, p=0.40$; Fig. $\left.6 E\right)$.

\section{Discussion}

Infusion of methylphenidate and atomoxetine into the anterior cingulate and infralimbic cortex, BLA and habenula inhibited social play behavior in rats. These effects were behaviorally specific because methylphenidate and atomoxetine did not inhibit social exploratory behavior or locomotor activity. Moreover, these effects were anatomically specific because infusion of methylphenidate into the prelimbic, medial/ventral orbitofrontal and ventrolateral orbitofrontal cortex, nucleus accumbens shell, and mediodorsal thalamus did not alter social play behavior.
$0.16, p=0.70 ; F_{\text {time }}(5,85)=31.69, p<0.001 ; F_{\text {time }} \times$ treatment $(5,85)$ $=0.34, p=0.89$ ) (Fig. $3 E$ ).

Treatment with atomoxetine in the infralimbic cortex (social play behavior: $n=10$; locomotor activity: vehicle $n=12$, atomoxetine $n=9)$ reduced pinning $\left(t_{(9)}=2.91, p=0.02\right)$ and pouncing $\left(t_{(9)}=3.55, p=0.01\right)$ and increased social exploration $\left(t_{(9)}=-2.27, p=0.05\right)$ (Fig. $\left.4 A-C\right)$. Intra-infralimbic cortex atomoxetine did not alter locomotor activity $\left(F_{\text {treatment }(1,19)}=0.14\right.$, $p=0.71 ; F_{\text {time }(5,95)}=26.78, p<0.001 ; F_{\text {time }} \times$ treatment $(5,95)=$ $0.44, p=0.82$; Fig. $4 E$ ).

After infusion of atomoxetine into the BLA (social play behavior: $n=6$; locomotor activity: vehicle $n=9$, atomoxetine $n=7$ ), a reduction in pinning $\left(t_{(5)}=3.34, p=0.02\right)$ and pouncing $\left(t_{(5)}=\right.$ $3.38, p=0.02$ ) (Fig. $5 A, B$ ) was found. Intra-BLA atomoxetine did not affect social exploration $\left(t_{(5)}=-1.78, p=0.14\right.$; Fig. $5 C$ ) or locomotor activity $\left(F_{\text {treatment }(1,14)}=0.89, p=0.36 ; F_{\text {time }(5,70)}=\right.$ $19.64, p<0.001 ; F_{\text {time }} \times$ treatment $(5,70)=1.95, p=0.10$; Fig. $\left.5 E\right)$.

When atomoxetine was infused into the habenula (social play behavior: $n=7$; locomotor activity: $n=8)$, pinning $\left(t_{(6)}=2.39\right.$,
Prefrontal mechanisms underlying the inhibition of social play behavior by methylphenidate

Methylphenidate and atomoxetine reduced social play behavior after administration into the anterior cingulate and infralimbic cortex. The prefrontal cortex is thought to mediate higher cognitive functions such as attention, planning, cognitive flexibility, and decision making (Miller and Cohen, 2001; Dalley et al., 2004; Robbins and Arnsten, 2009; Schoenbaum et al., 2009). Because social interactions are inherently complex and unpredictable, it is likely that frontal cortical regions subserve executive functions in social situations (Adolphs, 2003; Blakemore, 2008; Rilling et al., 2008), including social play behavior (Siviy and Panksepp, 2011; Vanderschuren and Trezza, 2014).

We have previously hypothesized that methylphenidate reduces social play by improving behavioral inhibition, that is, by suppressing a vigorous form of social behavior that is associated with diminished attention for the environment (Vanderschuren et al., 2008). Indeed, systemic methylphenidate and atomoxetine are known to improve behavioral inhibition in rats and humans, 
in paradigms such as the stop signal task (SST) and the 5-choice serial reaction time task (5-CSRTT) (Chamberlain and Sahakian, 2007; Eagle et al., 2008; Pattij and Vanderschuren, 2008). However, it has been reported recently that atomoxetine increases SST performance via the dorsal prelimbic and (ventrolateral) orbitofrontal, but not anterior cingulate or infralimbic cortex (Bari et al., 2011). Moreover, infusion of atomoxetine into the infralimbic cortex did not affect premature responding in the 5-CSRTT (Economidou et al., 2012). Therefore, if methylphenidate and atomoxetine reduce social play through enhanced or exaggerated inhibition of behavior, then this aspect of inhibition is probably distinct from the constructs analyzed in the SST and 5-CSRTT. Alternatively, the prefrontally mediated inhibition of social play by methylphenidate and atomoxetine may be related to impaired behavioral flexibility. Thus, depletion of noradrenaline from the ventromedial prefrontal cortex, including the infralimbic cortex (McGaughy et al., 2008) or the medial prefrontal cortex, including both the anterior cingulate and prelimbic cortex (Tait et al., 2007), disrupted extradimensional shifting in an attentional set-shifting task. Remarkably, although atomoxetine reversed the set-shifting deficit produced by noradrenergic depletion, it disrupted performance in sham-lesioned rats (Newman et al., 2008). In the context of social play, this suggests that noradrenergic mechanisms in the prefrontal cortex subserve the cognitive flexibility necessary to be able to respond to the changeable, often unpredictable behavior of a conspecific.

The finding that atomoxetine infusion into the anterior cingulate and infralimbic cortex mimicked the effect of methylphenidate on social play is consistent with a noradrenergic mechanism of action of methylphenidate. Methylphenidate blocks the reuptake of both dopamine and noradrenaline (Ferris and Tang, 1979; Ritz et al., 1987) and reuptake of dopamine in the prefrontal cortex mainly occurs through the noradrenaline transporter (Tanda et al., 1997; Yamamoto and Novotney, 1998; Morón et al., 2002). Therefore, intra-prefrontal blockade of the noradrenaline transporter also increases prefrontal dopamine neurotransmission. However, our previous findings that the effects of methylphenidate and amphetamine on social play behavior were not influenced by pretreatment with a dopamine receptor antagonist (Vanderschuren et al., 2008; Achterberg et al., 2014) indicate that enhanced prefrontal dopamine neurotransmission does not underlie the play-suppressant effects of methylphenidate and atomoxetine.

We have reported previously that functional inactivation of medial prefrontal subregions, i.e., the prelimbic, infralimbic, and medial/ventral orbitofrontal cortex, inhibits social play (van Kerkhof et al., 2013a). Interestingly, of these regions, only the infralimbic cortex was involved in the play-reducing effects of methylphenidate and atomoxetine. Together, these findings provide a view into the heterogeneity of the prefrontal functions involved in social play (Pellis et al., 2006; Bell et al., 2009). Therefore, in keeping with the functional heterogeneity of the prefrontal cortex (Chudasama et al., 2003; Killcross and Coutureau, 2003; Peters et al., 2009; Gourley et al., 2010), noradrenergic 0.001 , paired $t$ test.
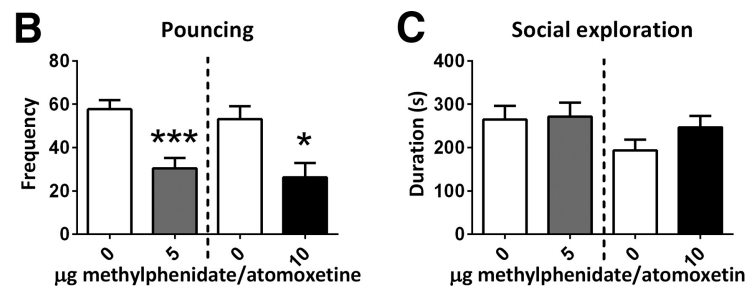

$\mu g$ methylphenidate/atomoxetin
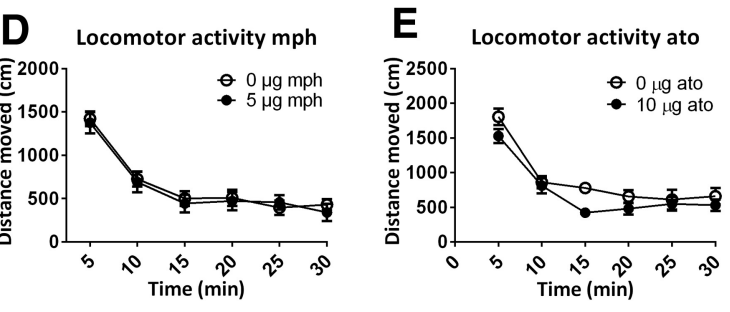

Figure 6. The effect of methylphenidate (mph; $5.0 \mu \mathrm{g} / 0.3 \mu \mathrm{l}$, gray bar; social play behavior, $n=9$; locomotor activity: $n=9$ ) or atomoxetine (ato; $10.0 \mu \mathrm{g} / 0.3 \mu \mathrm{l}$, black bar; social play behavior, $n=7$; locomotor activity: $n=8$ ) administration into the habenula decreased pinning $(\boldsymbol{A})$ and pouncing $(\boldsymbol{B})$, but not social exploration $(\boldsymbol{C})$ or locomotor activity $(\boldsymbol{D}, \boldsymbol{E}) .{ }^{*} p \leq 0.05,{ }^{* * *} p \leq$

mechanisms may underlie the functional involvement of the infralimbic and anterior cingulate, but not prelimbic and orbitofrontal cortex, suggesting that these prefrontal subregions are involved in distinct executive aspects of social play behavior.

Limbic subcortical mechanisms underlying the inhibition of social play behavior by methylphenidate

Methylphenidate and atomoxetine infusion into the BLA and the habenula, but not the nucleus accumbens shell or mediodorsal thalamus, suppressed social play behavior. Noradrenaline has been shown to reduce neuronal activity in the BLA via $\alpha 2$ adrenoceptors (Ferry et al., 1997; Buffalari and Grace, 2007; Johnson et al., 2011). Because stimulation of $\alpha 2$-adrenoceptors underlies the play-suppressant effect of methylphenidate (Vanderschuren et al., 2008), the inhibition of social play by methylphenidate and atomoxetine may be the result of reduced BLA output. This is consistent with previous findings that amygdala lesions reduce social play in male rats (Meaney et al., 1981; Daenen et al., 2002). In addition, systemic treatment with low doses of methylphenidate has been reported to decrease glucose metabolism in the habenula (Porrino and Lucignani, 1987), suggesting that enhancement of noradrenergic neurotransmission by methylphenidate and atomoxetine results in decreased habenula activity. Indeed, we have shown recently that functional inactivation of the habenula decreased social play behavior (van Kerkhof et al., 2013b).

Social play is a highly rewarding activity (Vanderschuren, 2010; Trezza et al., 2011b) and both the BLA and habenula are involved in reward processes (Baxter and Murray, 2002; Cardinal et al., 2002; Lecourtier and Kelly, 2007; Hikosaka, 2010; Morrison and Salzman, 2010). Indeed, we have found recently that endocannabinoid-mediated facilitation of social play, which may be related to increased reward value, occurs within the BLA (Trezza et al., 2012). Therefore, functional inhibition of the BLA and habenula by methylphenidate and atomoxetine may have reduced the positive emotional properties of social play. Alternatively, methylphenidate and atomoxetine in the BLA and habenula may have influenced cognitive aspects of social play, perhaps in concert with prefrontal regions (Pitkänen, 2000; Sah 
et al., 2003; Lecourtier and Kelly, 2007). For example, habenula lesions have been shown to disrupt attention (Lecourtier and Kelly, 2005) and the BLA has been implicated in behavioral flexibility (Schoenbaum et al., 2003; Churchwell et al., 2009). Last, both the habenula and BLA are involved in stress- and anxietyrelated behaviors (Phelps and LeDoux, 2005; Roozendaal et al., 2009; Hikosaka, 2010; Shin and Liberzon, 2010), but we consider it unlikely that changes in these latter processes explain the effects of methylphenidate and atomoxetine on social play behavior. Thus, intra-BLA and intra-habenula methylphenidate and atomoxetine did not affect social exploratory behavior, which is the standard parameter used in the social interaction test of anxiety (File and Seth, 2003). Moreover, pharmacological analysis of social play behavior has shown that anxiolytic or anxiogenic drugs do not invariably increase or reduce social play, respectively (Vanderschuren et al., 1997; Trezza et al., 2009a).

\section{Neurocircuitry of social play behavior}

Importantly, our present data show that the suppression of social play behavior by methylphenidate and atomoxetine is not exerted through a single brain region. Rather, methylphenidate and atomoxetine act in a distributed network of brain regions, likely affecting different emotional and cognitive aspects of social play behavior at the same time, which results in a profound inhibition of this behavior (Vanderschuren et al., 2008). The infralimbic cortex, anterior cingulate cortex, BLA, and habenula may therefore be part of an interconnected functional network involved in the modulation of social play behavior. Indeed, these four regions have reciprocal connections with the locus ceruleus (Moore and Bloom, 1979; Gottesfeld, 1983; Unnerstall et al., 1984; Jodo et al., 1998; Pitkänen, 2000; Vertes, 2004; Hoover and Vertes, 2007; Lecourtier and Kelly, 2007; Radley et al., 2008). Furthermore, the intralimbic cortex has reciprocal connections with the anterior cingulate cortex and both have reciprocal connections with the BLA (Pitkänen, 2000; Vertes, 2004; Hoover and Vertes, 2007). The infralimbic cortex also sends a moderate innervation to the habenula. Last, both the BLA and habenula send distributed outputs to the thalamus, which in turn innervates the prefrontal cortex (Groenewegen, 1988; De Olmos et al., 2004; Lecourtier and Kelly, 2007). Therefore, the four structures implicated in the effects of methylphenidate and atomoxetine on social play are intricately linked.

The social play parameters analyzed in the present study, pinning and pouncing, are the most characteristic behaviors observed during social play behavior in rats (Panksepp and Beatty, 1980). The present study suggests that these behaviors can be modulated by altering the underlying cognitive and emotional processes in social play, resulting in what may appear to be uniform reductions in social play. Clearly, even though manipulating noradrenergic transmission in prefrontal and subcortical limbic structures can have similar consequences for pinning and pouncing, the underlying cognitive and emotional processes are likely to be different. Therefore, future studies using place conditioning and operant conditioning can reveal whether these reductions in play behavior are the result of changes in the rewarding (Trezza et al., 2009b), cognitive (Achterberg et al., 2012), or motivational properties (van Kerkhof et al., 2012) of social play.

\section{Conclusion}

This study provides new insights into the neural underpinnings of a developmentally important social activity, as well as the behavioral mechanism of action of two drugs widely used for the treatment of ADHD. Our findings suggest that an interplay be- tween limbic cortical and subcortical structures underlies the integration of cognitive and emotional information during the proper execution of a playful social encounter.

\section{References}

Achterberg EJM, Trezza V, Vanderschuren LJMJ (2012) $\beta$-Adrenoreceptor stimulation mediates reconsolidation of social reward-related memories. PLoS One 7:e39639. CrossRef Medline

Achterberg EJM, Trezza V, Siviy SM, Schrama L, Schoffelmeer ANM, Vanderschuren LJMJ (2014) Amphetamine and cocaine suppress social play behavior in rats through distinct mechanisms. Psychopharmacology 231:1503-1515. CrossRef Medline

Adolphs R (2003) Cognitive neuroscience of human social behaviour. Nat Rev Neurosci 4:165-178. CrossRef Medline

Andersen SL (2005) Stimulants and the developing brain. Trends Pharmacol Sci 26:237-243. CrossRef Medline

Arnsten AF (2011) Catecholamine influences on dorsolateral prefrontal cortical networks. Biol Psychiatry 69:e89-e99. CrossRef Medline

Authier N, Dupuis E, Kwasiborski A, Eschalier A, Coudoré F (2002) Behavioural assessment of dimethylsulfoxide neurotoxicity in rats. Toxicol Lett 132:117-121. CrossRef Medline

Baarendse PJJ, Counotte DS, O’Donnell P, Vanderschuren LJMJ (2013) Early social experience is critical for the development of cognitive control and dopamine modulation of prefrontal cortex function. Neuropsychopharmacology 38:1485-1494. CrossRef Medline

Baenninger LP (1967) Comparison of behavioural development in socially isolated and grouped rats. Anim Behav 15:312-323. CrossRef Medline

Bari A, Mar AC, Theobald DE, Elands SA, Oganya KC, Eagle DM, Robbins TW (2011) Prefrontal and monoaminergic contributions to stop-signal task performance in rats. J Neurosci 31:9254-9263. CrossRef Medline

Baxter MG, Murray EA (2002) The amygdala and reward. Nat Rev Neurosci 3:563-573. CrossRef Medline

Beatty WW, Dodge AM, Dodge LJ, White K, Panksepp J (1982) Psychomotor stimulants, social deprivation and play in juvenile rats. Pharmacol Biochem Behav 16:417-422. CrossRef Medline

Beatty WW, Costello KB, Berry SL (1984) Suppression of play fighting by amphetamine: effects of catecholamine antagonists, agonists and synthesis inhibitors. Pharmacol Biochem Behav 20:747-755. CrossRef Medline

Bell HC, McCaffrey DR, Forgie ML, Kolb B, Pellis SM (2009) The role of the medial prefrontal cortex in the play fighting of rats. Behav Neurosci 123: 1158-1168. CrossRef Medline

Berridge CW, Stratford TL, Foote SL, Kelley AE (1997) Distribution of dopamine beta-hydroxylase-like immunoreactive fibers within the shell subregion of the nucleus accumbens. Synapse 27:230-241. CrossRef Medline

Berridge KC, Kringelbach ML (2013) Neuroscience of affect: brain mechanisms of pleasure and displeasure. Curr Opin Neurobiol 23:294-303. CrossRef Medline

Blakemore SJ (2008) The social brain in adolescence. Nat Rev Neurosci 9:267-277. CrossRef Medline

Block AE, Dhanji H, Thompson-Tardif SF, Floresco SB (2007) Thalamicprefrontal cortical-ventral striatal circuitry mediates dissociable components of strategy set shifting. Cereb Cortex 17:1625-1636. CrossRef Medline

Bolles RC, Woods PJ (1964) The ontogeny of behavior in the albino rat. Animal Behavior 12:427-441. CrossRef

Buffalari DM, Grace AA (2007) Noradrenergic modulation of basolateral amygdala neuronal activity: opposing influences of alpha-2 and beta receptor activation. J Neurosci 27:12358-12366. CrossRef Medline

Cardinal RN, Parkinson JA, Hall J, Everitt BJ (2002) Emotion and motivation: the role of the amygdala, ventral striatum, and prefrontal cortex. Neurosci Biobehav Rev 26:321-352. CrossRef Medline

Cavaletti G, Oggioni N, Sala F, Pezzoni G, Cavalletti E, Marmiroli P, Petruccioli MG, Frattola L, Tredici G (2000) Effect on the peripheral nervous system of systemically administered dimethylsulfoxide in the rat: a neurophysiological and pathological study. Toxicol Lett 118:103-107. CrossRef Medline

Chamberlain SR, Sahakian BJ (2007) The neuropsychiatry of impulsivity. Curr Opin Psychiatry 20:255-261. Medline

Chudasama Y, Bussey TJ, Muir JL (2001) Effects of selective thalamic and prelimbic cortex lesions on two types of visual discrimination and reversal learning. Eur J Neurosci 14:1009-1020. CrossRef Medline

Chudasama Y, Passetti F, Desai A, Rhodes SE, Lopian D, Robbins TW (2003) Dissociable aspects of performance on the 5-choice serial reaction time 
task following lesions of the dorsal anterior cingulate, infralimbic and orbitofrontal cortex in the rat: differential effects on selectivity, impulsivity and compulsivity. Behav Brain Res 146:105-119. CrossRef Medline

Churchwell JC, Morris AM, Heurtelou NM, Kesner RP (2009) Interactions between the prefrontal cortex and amygdala during delay discounting and reversal. Behav Neurosci 123:1185-1196. CrossRef Medline

Daenen EW, Wolterink G, Gerrits MAFM, Van Ree JM (2002) The effects of neonatal lesions in the amygdala or ventral hippocampus on social behavior later in life. Behav Brain Res 136:571-582. CrossRef Medline

Dalley JW, Cardinal RN, Robbins TW (2004) Prefrontal executive and cognitive functions in rodents: neural and neurochemical substrates. Neurosci Biobehav Rev 28:771-784. CrossRef Medline

Del Campo N, Chamberlain SR, Sahakian BJ, Robbins TW (2011) The roles of dopamine and noradrenaline in the pathophysiology and treatment of attention-deficit/hyperactivity disorder. Biol Psychiatry 69:e145-e157. CrossRef Medline

Delfs JM, Zhu Y, Druhan JP, Aston-Jones GS (1998) Origin of noradrenergic afferents to the shell subregion of the nucleus accumbens: anterograde and retrograde tract-tracing studies in the rat. Brain Res 806:127-140. CrossRef Medline

De Olmos JS, Beltramico CA, Alheid G (2004) Amygdala and extended amygdala of the rat: a cytoarchitectonical, fibroarchitectonical, and chemoarchitectonical survey. In: The rat nervous system (Paxinos G, ed), pp 509-603. San Diego: Elsevier Academic.

Eagle DM, Bari A, Robbins TW (2008) The neuropsychopharmacology of action inhibition: cross-species translation of the stop-signal and go/ no-go tasks. Psychopharmacology 199:439-456. CrossRef Medline

Economidou D, Theobald DE, Robbins TW, Everitt BJ, Dalley JW (2012) Norepinephrine and dopamine modulate impulsivity on the five-choice serial reaction time task through opponent actions in the shell and core sub-regions of the nucleus accumbens. Neuropsychopharmacology 37: 2057-2066. CrossRef Medline

Fagen R (1981) Animal play behavior. Oxford, Oxford UP.

Feldman HM, Reiff MI (2014) Clinical practice. Attention deficithyperactivity disorder in children and adolescents. N Engl J Med 370: 838-846. CrossRef Medline

Ferris RM, Tang FL (1979) Comparison of the effects of the isomers of amphetamine, methylphenidate and deoxypipradrol on the uptake of 1- $\left[{ }^{3} \mathrm{H}\right]$ norepinephrine and $\left[{ }^{3} \mathrm{H}\right]$ dopamine by synaptic vesicles from rat whole brain, striatum and hypothalamus. J Pharmacol Exp Ther 210:422428. Medline

Ferry B, Magistretti PJ, Pralong E (1997) Noradrenaline modulates glutamate-mediated neurotransmission in the rat basolateral amygdala in vitro. Eur J Neurosci 9:1356-1364. CrossRef Medline

File SE, Seth P (2003) A review of 25 years of the social interaction test. Eur J Pharmacol 463:35-53. CrossRef Medline

Gottesfeld Z (1983) Origin and distribution of noradrenergic innervation in the habenula: a neurochemical study. Brain Res 275:299-304. CrossRef Medline

Gourley SL, Lee AS, Howell JL, Pittenger C, Taylor JR (2010) Dissociable regulation of instrumental action within mouse prefrontal cortex. Eur J Neurosci 32:1726-1734. CrossRef Medline

Graham KL, Burghardt GM (2010) Current perspectives on the biological study of play: signs of progress. Q Rev Biol 85:393-418. Medline

Groenewegen HJ (1988) Organization of the afferent connections of the mediodorsal thalamic nucleus in the rat, related to the mediodorsalprefrontal topography. Neuroscience 24:379-431. CrossRef Medline

Hikosaka O (2010) The habenula: from stress evasion to value-based decision-making. Nat Rev Neurosci 11:503-513. CrossRef Medline

Hoover WB, Vertes RP (2007) Anatomical analysis of afferent projections to the medial prefrontal cortex in the rat. Brain Struct Funct 212:149-179. CrossRef Medline

Jodo E, Chiang C, Aston-Jones G (1998) Potent excitatory influence of prefrontal cortex activity on noradrenergic locus ceruleus neurons. Neuroscience 83:63-79. CrossRef Medline

Johnson LR, Hou M, Prager EM, Ledoux JE (2011) Regulation of the fear network by mediators of stress: norepinephrine alters the balance between cortical and subcortical afferent excitation of the lateral amygdala. Front Behav Neurosci 5:23. CrossRef Medline

Killcross S, Coutureau E (2003) Coordination of actions and habits in the medial prefrontal cortex of rats. Cereb Cortex 13:400-408. CrossRef Medline

Kratochvil CJ, Wilens TE, Greenhill LL, Gao H, Baker KD, Feldman PD,
Gelowitz DL (2006) Effects of long-term atomoxetine treatment for young children with attention-deficit/hyperactivity disorder. J Am Acad Child Adolesc Psychiatry 45:919-927. CrossRef Medline

Kutcher S, Aman M, Brooks SJ, Buitelaar J, van Daalen E, Fegert J, Findling RL, Fisman S, Greenhill LL, Huss M, Kusumakar V, Pine D, Taylor E, Tyano S (2004) International consensus statement on attention-deficit/ hyperactivity disorder (ADHD) and disruptive behavior disorders (DBDs): clinical implications and treatment practice suggestions. Eur Neuropsychopharmacol 14:11-28. CrossRef Medline

Lecourtier L, Kelly PH (2005) Bilateral lesions of the habenula induce attentional disturbances in rats. Neuropsychopharmacology 30:484-496. CrossRef Medline

Lecourtier L, Kelly PH (2007) A conductor hidden in the orchestra? Role of the habenular complex in monoamine transmission and cognition. Neurosci Biobehav Rev 31:658-672. CrossRef Medline

McAlonan GM, Robbins TW, Everitt BJ (1993) Effects of medial dorsal thalamic and ventral pallidal lesions on the acquisition of a conditioned place preference: further evidence for the involvement of the ventral striatopallidal system in reward-related processes. Neuroscience 52:605-620. CrossRef Medline

McGaughy J, Ross RS, Eichenbaum H (2008) Noradrenergic, but not cholinergic, deafferentation of prefrontal cortex impairs attentional setshifting. Neuroscience 153:63-71. CrossRef Medline

Meaney MJ, Dodge AM, Beatty WW (1981) Sex-dependent effects of amygdaloid lesions on the social play of prepubertal rats. Physiol Behav 26:467472. CrossRef Medline

Miller EK, Cohen JD (2001) An integrative theory of prefrontal cortex function. Annu Rev Neurosci 24:167-202. CrossRef Medline

Moore RY, Bloom FE (1979) Central catecholamine neuron systems: anatomy and physiology of the norepinephrine and epinephrine systems. Annu Rev Neurosci 2:113-168. CrossRef Medline

Morón JA, Brockington A, Wise RA, Rocha BA, Hope BT (2002) Dopamine uptake through the norepinephrine transporter in brain regions with low levels of the dopamine transporter: evidence from knock-out mouse lines. J Neurosci 22:389-395. Medline

Morrison SE, Salzman CD (2010) Re-valuing the amygdala. Curr Opin Neurobiol 20:221-230. CrossRef Medline

Newman LA, Darling J, McGaughy J (2008) Atomoxetine reverses attentional deficits produced by noradrenergic deafferentation of medial prefrontal cortex. Psychopharmacology 200:39-50. CrossRef Medline

Panksepp J, Beatty WW (1980) Social deprivation and play in rats. Behav Neural Biol 30:197-206. CrossRef Medline

Panksepp J, Siviy S, Normansell L (1984) The psychobiology of play: theoretical and methodological perspectives. Neurosci Biobehav Rev 8:465492. CrossRef Medline

Panksepp J, Normansell L, Cox JF, Siviy SM (1994) Effects of neonatal decortication on the social play of juvenile rats. Physiol Behav 56:429-443. CrossRef Medline

Pattij T, Vanderschuren LJMJ (2008) The neuropharmacology of impulsive behavior. Trends Pharmacol Sci 29:192-199. CrossRef Medline

Paxinos G, Watson C (2007) The rat brain in stereotaxic coordinates. London, Academic.

Pellis SM, McKenna MM (1992) Intrinsic and extrinsic influences on play fighting in rats: effects of dominance, partner's playfulness, temperament and neonatal exposure to testosterone propionate. Behav Brain Res 50: 135-145. CrossRef Medline

Pellis SM, Pellis VC (1987) Play-fighting differs from serious fighting in both target of attack and tactics of fighting in the laboratory rat Rattus norvegicus. Aggressive Behavior 13:227-242. CrossRef

Pellis SM, Pellis VC (1998) Play fighting of rats in comparative perspective: a schema for neurobehavioral analyses. Neurosci Biobehav Rev 23:87101. CrossRef Medline

Pellis SM, Pellis VC (2009) The playful brain. Oxford: OneWorld Publications.

Pellis SM, Pellis VC, Dewsbury DA (1989) Different levels of complexity in the play-fighting by muroid rodents appear to result from different levels of intensity of attack and defense. Aggressive Behavior 15:297-310. CrossRef

Pellis SM, Hastings E, Shimizu T, Kamitakahara H, Komorowska J, Forgie ML, Kolb B (2006) The effects of orbital frontal cortex damage on the modulation of defensive responses by rats in playful and nonplayful social contexts. Behav Neurosci 120:72-84. CrossRef Medline 
Peters J, Kalivas PW, Quirk GJ (2009) Extinction circuits for fear and addiction overlap in prefrontal cortex. Learn Mem 16:279-288. CrossRef Medline

Phelps EA, LeDoux JE (2005) Contributions of the amygdala to emotion processing: from animal models to human behavior. Neuron 48:175-187. CrossRef Medline

Pitkänen A (2000) Connectivity of the rat amygdaloid complex. In: The amygdala: a functional analysis (Aggleton JP, ed). pp 32-115. Oxford, OUP.

Poole TB, Fish J (1975) Investigation of playful behavior in Rattus norvegicus and Mus musculus (Mammalia). Journal of Zoology 175:61-71.

Porrino LJ, Lucignani G (1987) Different patterns of local brain energy metabolism associated with high and low doses of methylphenidate: relevance to its action in hyperactive children. Biol Psychiatry 22:126-138. CrossRef Medline

Radley JJ, Williams B, Sawchenko PE (2008) Noradrenergic innervation of the dorsal medial prefrontal cortex modulates hypothalamo-pituitaryadrenal responses to acute emotional stress. J Neurosci 28:5806-5816. CrossRef Medline

Rilling JK, King-Casas B, Sanfey AG (2008) The neurobiology of social decision-making. Curr Opin Neurobiol 18:159-165. CrossRef Medline

Ritz MC, Lamb RJ, Goldberg SR, Kuhar MJ (1987) Cocaine receptors on dopamine transporters are related to self-administration of cocaine. Science 237:1219-1223. CrossRef Medline

Robbins TW, Arnsten AF (2009) The neuropsychopharmacology of frontoexecutive function: monoaminergic modulation. Annu Rev Neurosci 32: 267-287. CrossRef Medline

Roozendaal B, McEwen BS, Chattarji S (2009) Stress, memory and the amygdala. Nat Rev Neurosci 10:423-433. CrossRef Medline

Sah P, Faber ES, Lopez De Armentia M, Power J (2003) The amygdaloid complex: anatomy and physiology. Physiol Rev 83:803-834. CrossRef Medline

Schneider M, Koch M (2005) Deficient social and play behavior in juvenile and adult rats after neonatal cortical lesion: effects of chronic pubertal cannabinoid treatment. Neuropsychopharmacology 30:944-957. CrossRef Medline

Schoenbaum G, Setlow B, Nugent SL, Saddoris MP, Gallagher M (2003) Lesions of orbitofrontal cortex and basolateral amygdala complex disrupt acquisition of odor-guided discriminations and reversals. Learn Mem 10:129-140. CrossRef Medline

Schoenbaum G, Roesch MR, Stalnaker TA, Takahashi YK (2009) A new perspective on the role of the orbitofrontal cortex in adaptive behaviour. Nat Rev Neurosci 10:885-892. CrossRef Medline

Shin LM, Liberzon I (2010) The neurocircuitry of fear, stress, and anxiety disorders. Neuropsychopharmacology 35:169-191. CrossRef Medline

Siviy SM, Panksepp J (1985) Dorsomedial diencephalic involvement in the juvenile play of rats. Behav Neurosci 99:1103-1113. CrossRef Medline

Siviy SM, Panksepp J (2011) In search of the neurobiological substrates for social playfulness in mammalian brains. Neurosci Biobehav Rev 35:18211830. CrossRef Medline

Špinka M, Newberry RC, Bekoff M (2001) Mammalian play: training for the unexpected. Q Rev Biol 76:141-168. CrossRef Medline

Sutton ME, Raskin LA (1986) A behavioral analysis of the effects of amphetamine on play and locomotor activity in the post-weaning rat. Pharmacol Biochem Behav 24:455-461. CrossRef Medline

Tait DS, Brown VJ, Farovik A, Theobald DE, Dalley JW, Robbins TW (2007) Lesions of the dorsal noradrenergic bundle impair attentional set-shifting in the rat. Eur J Neurosci 25:3719-3724. CrossRef Medline

Tanda G, Pontieri FE, Frau R, Di Chiara G (1997) Contribution of blockade of the noradrenaline carrier to the increase of extracellular dopamine in the rat prefrontal cortex by amphetamine and cocaine. Eur J Neurosci 9:2077-2085. CrossRef Medline

Thor DH, Holloway WR Jr (1983) Play soliciting in juvenile male rats: effects of caffeine, amphetamine and methylphenidate. Pharmacol Biochem Behav 19:725-727. CrossRef Medline

Trezza V, Vanderschuren LJMJ (2008) Cannabinoid and opioid modulation of social play behavior in adolescent rats: differential behavioral mechanisms. Eur Neuropsychopharmacol 18:519-530. CrossRef Medline

Trezza V, Baarendse PJJ, Vanderschuren LJMJ (2009a) Prosocial effects of nicotine and ethanol in adolescent rats through partially dissociable neu- robehavioral mechanisms. Neuropsychopharmacology 34:2560-2573. CrossRef Medline

Trezza V, Damsteegt R, Vanderschuren LJMJ (2009b) Conditioned placepreference induced by social play behavior: parametrics, extinction, reinstatement and disruption by methylphenidate. Eur Neuropsychopharmacol 19: 659-669. CrossRef Medline

Trezza V, Baarendse PJJ, Vanderschuren LJMJ (2010) The pleasures of play: pharmacological insights into social reward mechanisms. Trends Pharmacol Sci 31:463-469. CrossRef Medline

Trezza V, Damsteegt R, Achterberg EJM, Vanderschuren LJMJ (2011a) Nucleus accumbens mu-opioid receptors mediate social reward. J Neurosci 31:6362-6370. CrossRef Medline

Trezza V, Campolongo P, Vanderschuren LJMJ (2011b) Evaluating the rewarding nature of social interactions in laboratory animals. Dev Cogn Neurosci 1:444-458. CrossRef Medline

Trezza V, Damsteegt R, Manduca A, Petrosino S, van Kerkhof LWM, Pasterkamp RJ, Zhou Y, Campolongo P, Cuomo V, Di Marzo V, Vanderschuren LJMJ (2012) Endocannabinoids in amygdala and nucleus accumbens mediate social play reward in adolescent rats. J Neurosci 32: 14899-14908. CrossRef Medline

Tye KM, Tye LD, Cone JJ, Hekkelman EF, Janak PH, Bonci A (2010) Methylphenidate facilitates learning-induced amygdala plasticity. Nat Neurosci 13:475-481. CrossRef Medline

Unnerstall JR, Kopajtic TA, Kuhar MJ (1984) Distribution of alpha 2 agonist binding sites in the rat and human central nervous system: analysis of some functional, anatomic correlates of the pharmacologic effects of clonidine and related adrenergic agents. Brain Res 319:69-101. Medline

van Kerkhof LWM, Achterberg EJM, Lesscher HMB, Trezza V, Vanderschuren LJMJ (2012) Dissociating the rewarding and motivational properties of social play behavior in adolescent rats: the role of dopamine, opioids and endocannabinoids. Soc Neurosci Abs 295.06.

van Kerkhof LWM, Damsteegt R, Trezza V, Voorn P, Vanderschuren LJM] (2013a) Social play behavior in adolescent rats is mediated by functional activity in medial prefrontal cortex and striatum. Neuropsychopharmacology 38:1899-1909. CrossRef Medline

van Kerkhof LWM, Damsteegt R, Trezza V, Voorn P, Vanderschuren LJMJ (2013b) Functional integrity of the habenula is necessary for social play behavior in adolescent rats. Eur J Neurosci 38:3465-3475. CrossRef Medline

van Kerkhof LWM, Trezza V, Mulder T, Gao P, Voorn P, Vanderschuren LJM] (2014) Cellular activation in limbic brain systems during social play behaviour in rats. Brain Struct Funct 219:1181-1211. CrossRef Medline

Vanderschuren LJMJ (2010) How the brain makes play fun. American Journal of Play 2:315-337.

Vanderschuren LJMJ, Trezza V (2014) What the laboratory rat has taught us about social play behavior: role in behavioral development and neural mechanisms. Curr Top Behav Neurosci 16:189-212. Medline

Vanderschuren LJMJ, Spruijt BM, Hol T, Niesink RJM, Van Ree JM (1995) Sequential analysis of social play behavior in juvenile rats: effects of morphine. Behav Brain Res 72:89-95. CrossRef Medline

Vanderschuren LJMJ, Niesink RJM, Van Ree JM (1997) The neurobiology of social play behavior in rats. Neurosci Biobehav Rev 21:309-326. CrossRef Medline

Vanderschuren LJMJ, Trezza V, Griffioen-Roose S, Schiepers OJ, Van Leeuwen N, De Vries TJ, Schoffelmeer ANM (2008) Methylphenidate disrupts social play behavior in adolescent rats. Neuropsychopharmacology 33:2946-2956. CrossRef Medline

Veeneman MMJ, Boleij H, Broekhoven MH, Snoeren EMS, Guitart Masip M, Cousijn J, Spooren W, Vanderschuren LJMJ (2011) Dissociable roles of mGlu5 and dopamine receptors in the rewarding and sensitizing properties of morphine and cocaine. Psychopharmacology 214:863-876. CrossRef Medline

Vertes RP (2004) Differential projections of the infralimbic and prelimbic cortex in the rat. Synapse 51:32-58. CrossRef Medline

Yamamoto BK, Novotney S (1998) Regulation of extracellular dopamine by the norepinephrine transporter. J Neurochem 71:274-280. CrossRef Medline

Zheng X, Liu F, Wu X, Li B (2008) Infusion of methylphenidate into the basolateral nucleus of amygdala or anterior cingulate cortex enhances fear memory consolidation in rats. Sci China C Life Sci 51:808-813. CrossRef Medline 